Jurnal Konstruksi Hukum | ISSN: 2746-5055

Vol. 2, No. 2, Mei $2021 \mathrm{Hal}$. 379-383| Tersedia online di

https://www.ejournal.warmadewa.ac.id/index.php/jukonhum

DOI: https://doi.org/10.22225/jkh.2.2.3259.379-383

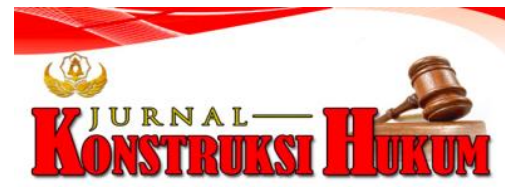

\title{
EKSISTENSI PERKAWINAN ENDOGAMI DI DESA ADAT TENGANAN PEGRINGSINGAN KARANGASEM
}

\author{
I Gede Bagus Indra Baskara, I Made Suwitra, I Ketut Sukadan \\ Fakultas Hukum Universitas Warmadewa, Denpasar-Bali, Indonesia \\ Indrabaskara334@yahoo.com, madesuwitra27@gmail.com, sukadanakerut1966@gmail.com
}

\begin{abstract}
Abstrak
Bali merupakan daerah yang memiliki keunikan dan tradisi masing-masing di masing-masing Desa termasuk dalam perkawinan. Desa adat Tenganan memiliki ciri khas dan tradisi yang berbeda dari desa lain yaitu sistem perkawinannya harus dilakukan secara endogami. Penelitian ini bertujuan untuk menjelaskan status krama desa pihak laki-laki yang kawin dengan pihak wanita dari luar Desa Tenganan dan mngetahui sanksi adat bagi lakilaki yang melakukan perkawinan dengan wanita dari luar Desa Tenganan. Penelitian didesain dengan penelitian hukum empiris, dengan pendekatan yuridis sosiologis, pendekatan secara perundang-undangan. Adapun data yang digunakan adalah data primer, data sekunder. Lokasi penelitian di Desa Adat Tenganan, Kecamatan Manggis, Karangasem, Bali. Data diperoleh dengan menggunakan teknik non probability sampling, pengamatan, wawancara. Selanjutnya data diolah dan dianalisis secara deskriptif kualitatif. Hasil penelitian menunjukkan bahwa Perkawinan yang dilangsungkan antara laki-laki dari Desa Tenganan dengan perempuan dari luar Desa Tenganan yang masih bisa diajak di Desa Tenganan adalah perempuan yang mempunyai kasta atau berasal dari warga pasek. Sanksi bagi laki-laki dari Desa Tenganan yang kawin dengan perempuan dari luar Desa Tenganan berupa sanksi penurunan status krama, dari krama desa menjadi krama gumi pulangan tidak lagi menjadi krama desa dan juga tidak ikut ngayah di Pura Bale Agung.
\end{abstract}

Kata Kunci : Endogami, Desa Adat Tenganan, Perkawinan

\begin{abstract}
Bali is an area that has its own uniqueness and traditions in each village, including marriage. The traditional village of Tenganan has different characteristics and traditions from other villages, namely that the marriage system must be endogamous. This study aims to explain the status of village manners for men who marry women from outside Tenganan Village and to find out the customary sanctions for men who marry women from outside Tenganan Village. The research was designed with empirical legal research, with a sociological juridical approach, a statutory approach. The data used are primary data and secondary data. The research location is in the Tenganan Traditional Village, Manggis District, Karangasem, Bali. Data obtained using non probability sampling techniques, observations, interviews. Furthermore, the data is processed and analyzed descriptively qualitatively. The results showed that marriages between men from Tenganan Village and women from outside Tenganan Village who can still be invited in Tenganan Village are women who have caste or come from Pasek residents. Sanctions for men from Tenganan Village who marry women from outside Tenganan Village are in the form of sanctions decreasing the status of krama, from village krama to krama gumi home no longer becoming village manners and also not taking part in ngayah at Bale Agung Temple.
\end{abstract}

Keywords: Endogamy, Tenganan Traditional Village, Marriage

\section{PENDAHULUAN}

Perkawinan telah menjdi satu rangkaian kejadian hukum penting dalam kehidupan manusia dengan berbagai macam konsekuensi pada hukumnya. Oleh sebab itu hukumlah yang mengatur mengenai masalah perkawinan secara lengkap dan mendetail. Pengertian dari perkawinan merupakan proses ikatan secara lahir dan batin antara seorang pria dan seorang wanita unruk menjadi suami-istri yang bertujuan unruk mernbentuk keluarga yang kekal, harmonis dan bahagia berdasarkan kepada Ketuhanan Yang Maha Esa dan wajib dicatatkan sesuai ketentuan peraturan perundang-undangan yang berlaku di Indonesia (Fuady, 2014). Adanya hukum seperti itu tentunya dimaksudkan untuk mengkoordinir kepentingan-kepentingan dari setiap orang agar tidak saling berlawanan antara kepentingan satu dengan oarang lain.

Suatu proses perkawinan dapat dikatakan sebagai perbuatan hukum artinya perkawinan tersebut dapat membawa dampak secara hukum dengan timbulnya hak beserta kewajiban dari masing-masing 
para pihak (Aristoni \& Abdullah, 2016). Perkawinan kadang menimbulkan dampak terhadap hak serta kewajiban, mulai administrasi yang memberikan kewenangan pada Negara dengan menemukan keabsahan starusnya dari masing-masing pihak termasuk juga adanya hubungan hukum dengan pihak ketiga misalkan antara pihak menantu dengan mertuanya. Norma hukum dalam perkawinan salah satunya mengatur mengenai bagaimana suatu hubungan hukum suami-istri wajib disetujui, disaksikan serta disahkan dalam hubungannya dengan keabsahan pada kehidupan sehari-sehari dengan ritual (Dornikus, 2015). Hukum adat mengartikan perkawinan merupakan suatu hal yang penting karena tidak hanya mengenai hubungan antara para pihak mempelai melainkan juga mengenai adanya hubungan hukum dari kedua belah pihak seperti saudara-saudara dan keluarga mereka akan mempunyai hubungan hukum baru dengan orang baru. Bahkan diyakini dalam hukum adat bahwa suatu perkawinan tidak saja menjadi penting untuk mereka yang masih hidup melainkan sebagai rangkaian penting untuk leluhur dari masing-masing pihak yang sudah tiada.

Cara dari adat di Desa Tenganan Pegringsingan melakukan perkawinan berbeda dari desa-desa lainnya, yaitu adanya ciri khusus pada perkawinannya. Adat perkawinan endogami merupakan perkawinan yang dilakukan harus dilaksanakan antara seorang pria (teruna) dengan seorang wanita (deha) dari Desa Tenganan Pegringsingan. Desa Tenganan Pegringsingan suatu perkawinan dianggap sudah sah apabila telah dilaksanakan upacara perkawinannya yang disebut mebyakaon dan seorang pria hanya bisa mempunyai seorang istri. Hal ini sering disebut dengan perkawinan yang menganut asas monogami. Akibat dari dilaksanakannya perkawinan, istri yang sudah dinikahi tidak dilepaskan dari asal keluarganya, melainkan istri masuk menjadi keluarga suami dan suami masuk menjadi keluarga istri juga serta kedudukan dari si suami-istri tersebut dalam perkawinan menjadi sama. Jika seorang pria dari Desa Tenganan Pegringsingan menikahi wanita dari luar Desa Tenganan Pegringsingan kecuali wanita tersebut warga dari pasek, maka pria tersebut tidak lagi diakui sebagai bagian warga masyarakat Desa Tenganan Pegringsingan ataupun tidak diperkenankan lagi berstarus sebagai krama desa dan dibuang/ditempatkan di Banjar Pande yang berada di sebelah Timur Desa Tenganan Pegringsingan.

Penelitian terdahulu Sumunar et al., (2017) mengungkapkan Ajaran gama Hindu membuat keseimbangan antara manusia dengan Tuhan, manusia dengan manusia dan manusia dengan lingkungannya, sehingga semua masyarakat yang tinggal dalam satu desa tersebut wajib melaksnakan ketentuan-ketentuan adat diberbagai aspek kehidupan salah satunya saat melakukan perkawinan, seorang lelaki wajim mematuhi adat perkawinan Endogami. Penelitian lain Sudarma \& Wisuda, (2018); (Yogantara, 2018) mengungkapkan masyarakat Desa adat Tenganan masih kental dengan adat perkawinan Endogami, dan sanksi adat terhadap pelanggaran perkawinan endogami difokuskan pada sanksi sosial dengan melakukan pengasingan dari desa tersebut. Berdasarkan latar belakang permasalahan di atas, penelitian dilakukan dengan tujuan menjelaskan status krama desa pihak laki-laki yang kawin dengan pihak wanita dari luar Desa Tenganan dan mngetahui sanksi adat bagi laki-laki yang melakukan perkawinan dengan wanita dari luar Desa Tenganan.

\section{METODE PENELITIAN}

Penelitian ini didesain dengan penelitian hukum empiris, dengan pendekatan yuridis sosiologis, pendekatan secara perundang-undangan. Adapun data yang digunakan adalah data primer dan data sekunder. Bahan hukum primer yang digunakan bersumber dari peraturan perundang-undangan yaitu Undang-Undang Dasar Negara Republik Indonesia Tahun 1945, Undang-Undang Republik Indonesia Nomor 16 Tahun 2019 tentang perubahan atas Undang-Undang Nomor 1 Tahun 1974 tentang Perkawinan dan Awig-Awig Lan Paweweh Awig Desa Adat Tenganan Pegringsingan. Bahan hukum sekunder yaitu bahan hukum yang memberi penjelasan mengenai bahan hukum primer, seperti, bukubuku hukum, karya ilmiah dan awig-awig. Data diperoleh dengan teknik probability sampling, pengamatan, wawancara. Setelah data terkumpul, selanjutnay dianalisis secara kulaitatif deskriptif (Sugiyono, 2013).

\section{HASIL DAN PEMBAHASAN}




\section{Status Krama Desa Pihak Laki-Laki yang Kawin dengan Pihak Wanita Dari Luar Desa Adat Tenganan Pegringsingan}

berdasarkan hukum Agama Hindu wiwaha (perkawinan) merupakan suatu ikatan antara seorang pria dan seorang wanita sebagai suami-istri untuk mengatur hubungan seks yang layak, guna untuk mendapatkan keturunan anak yang akan menyelamatkan arwah atau roh orang tuanya dari neraka yang dilangsungkan dengan upacara ritual. Sesuai Agama Hindu Weda Smrti, Jika dari perkawinan itu tidak dilangsungkan dengan rangkain upacara sesuai hukum Agama Hindu, maka rangkaian dan perkawinan itu menjadi tidak sah (Ketut, 2008). Akibat hukum dari sebelum adanya perkawinan adalah hubungan pelamaran antara laki-laki denagn wanita serta hubungan dari para calon suami-istri (Hadikusuma, 2007).

Pada sistem keragaman dari hukum adat yang ada di Indonesia, ada salah satunya dikenal dengan sistem endogami artinya jika seseorang yang ingin melangsungkan pernikahan diwajibkan untuk memilih pasangan hidup yang berasal dari wilayah desa atau sukunya sendiri. Daerah penganut sistem ini diantaranya adalah Toraja dan juga salah satunya Desa Adat Tenganan Pegringsingan di Bali.

Desa Tenganan Pegringsingan merupakan komunitas atau yang bersifat organisasi teritorial yang bersifat gabungan (kolektif) dan masih memegang teguh budaya-budaya tradisionalnnya secara bersarna-sama masyarakat adat senantiasa menjaga kesucian desa mereka. Makna dari kolektif berarti bahwa masyarakat ada untuk desa, kepentingan desa harus didahulukan dibandingkan kepentingan pribadi, Penduduk di Desa Tenganan terdiri dari 2 (dua) golongan yaitu golongan orang asli Tenganan Pegringsingan dan golongan orang-orang pendatang (Wong Angendok Jenek), namun pada strukrur adat mereka dibedakan menjadi 3 (tiga) yaitu krama desa, krama gumi pulangan dan krama gumi. Status warga adat di Desa Tenganan Pegringsingan yang dimaksud dengan krama desa adalah orang asli Tenganan Pegringsingan adalah penduduk atau orang-orang yang tinggal di Ban jar Kauh dan BanjarTengah, serta berhak duduk sebagai krama desa Adat Tenganan Pegringsingan. Golongan masyarakat yang menjadi krama desa inilah bertugas sebagai pengurus desa adat dan memiliki hakhak lebih dari golongan lainnya, ketentuan ini berlaku sepanjang kedudukan mereka tidak digugurkan dengan hukuman sesuai dengan ketentuan aturan adat. Sedangkan yang dimaksud dengan krama gumi pulangan salah sarunya adalah laki-laki orang Tenganan asli yang kawin dengan seorang wanita dari luar Tenganan maka laki-laki dan istrinnya tersebut akan menjadi krama gumi pulangan. Selanjutnya krama gumi adalah mereka-rnereka walaupun bertempat tinggal di Banjar Kauh dan di Banjar Tengah karena sejak lahirnya cacat fisik, maka hak dan kewajibannya hilang.

Menurut kelian adat Desa Tenganan I Wayan Rustana mengatakan bahwa jika pihak laki-laki dari Desa Adat Tenganan melangsungkan perkawinan dengan perempuan yang dari luar Desa Adat Tenganan kasta yang dimiliki harus lebih tinggi (menak) seperti anak Dayu (sebutan untuk anak perempuan berkasta di Bali) atau bisa juga warga pasek untuk diajak tinggal di Desa Adat Tenganan Pegringsingan. Warga pasek dikecualikan karena pada saat Upacara Ngaben memakai damar kurung hidup dan sawunya dibakar. Pihak laki-laki tersebut juga statusnya bukan lagi sebagai krama desa adat tetapi disebut sebagai krama gumi pulangan dan yang perempuan juga bukan masuk sebagai krama desa adat tetapi menjadi krama gumi pulangan. Tenganan Pegringsingan dan ngayah di Pura Bale Agung Tenganan. Krama gumi pulangan adalah orang dari Desa Adat Tenganan pegringsingan yang kawin keluar dengan orang yang mempunyai kasta atau orang pasek dan tinggal di Desa Adat Tenganan Pegringsingan, tetapi statusnya bukan lagi menjadi krama desa adat di Tenganan. Krama desa adat ayah-ayahan berada di Pura Bale Agung jika setiap ada upacara keagamaan, berbeda hal dengan krama gumi pulangan hanya pada hari tertentu saja, tidak setiap saat melaksanakan ngayab di Pura Bale Agung. Hasil-hasil seperti sawah dan sebagainya setiap krama juga sudah mempunyai hasil-hasilnya tersendiri dan sudah dibagi-bagi setiap krama. Pihak laki-laki dari Desa Adat Tenganan Pegringsingan yang melangsungkan perkawinan dengan perempuan tidak mempunyai kasta dan bukan juga warga pasek, maka tidak diizinkan untuk tinggal di Desa Tenganan Pegringsingan, tetapi akan ditempatkan istilahnya ke daerah Banjar Pande. Jika pihak perempuan dari Desa Adat Tenganan Pegringsingan yang kawin keluar maka statusnya sudah dianggap seperti dibuang dari Desa Adat Tenganan Pegringsingan. Apabila juga si perempuan dari Desa Adat Tenganan yang kawin keluar ini cerai pada suatu waktu, maka perempuan itu tidak dapat lagi kembali ke Desa Adat Tenganan Pegringsingan untuk menjadi krama Desa Adat Tenganan (wawancara dengan I Wayan Rustana tanggal I Desember 2020). 
Selanjutnaya responden bernama I Made Sudiarsana menyatakan ia sudah menikah hampir 8 tahun, merupakan asli warga Desa Adat Tenganan dan istrinya berasal dari Bangli, Kintamani, sekarang status saya berubah dari krama desa menjadi krama gumi pulangan, karena istrinya orang/warga pasek juga sehingga bisa tinggal di Desa Adat Tenganan dan masuk menjadi krama gumi pulangan, Warga pasek bisa dikecualikan juga diterima di Desa Tenganan karena Upacara Ngaben memakai damar kurung hidup tru seperti halnya juga warga pande karena yang meninggal sawunya dibakar bisa tinggal di Desa Adat Tenganan, yang tidak dibakar sawunya tidak bisa tinggal di Desa Adat Tenganan Pegringsingan. Kalau pihak laki-laki dari Desa Adat Tenganan Pegringsingan kawin dengan perempuan diluar Desa Adat Tenganan yang tidak menak dan bukan warga pasek ditempatkan di Ban jar Pande, karena orang Banjar Pande tidak ikut upacara di Desa Tenganan

\section{Sanksi Adat Bagi Pihak Laki-Laki yang Melakukan Perkawinan dengan Wanita Dari Luar Desa Adat Tenganan Pegringsingan}

Mengenai pelaksanaan perkawinan endogami pada acara perkawinan antara pihak laki-laki dan pihak perempuan sudah adanya hubungan cinta sama cinta ataupun suka sama suka. Perkawinan di Desa Tenganan Pergingsingan hanya bisa dilaksanakan oleh pria yang sudah dewasa (teruna) dan perempuan yang sudah dewasa (deha) yang didahuJui dengan suatu peristiwa antara peristiwa antara laki-laki dan perempuan yang ingin menikah dalam suatu asrama untuk diberikan pembekalan, pembelajaran dan bimbingan oleh ketua adat atau dari tokoh adat setempat untuk menjadi seseorang yang dewasa yang diharapkan mampu menjalankan perkawinannya dengan baik, sebelum nantinya perkawinan itu benar terlaksana.

Pihak dari pria (teruna) yang berasal dari Desa Tenganan Pegringsingan yang melangsungkan perkawinan dengan perempuan dari luar Desa Adat Tenganan sanksi berupa denda tidaklah ada hanya akan kehilangan hak dan kewajibannya serta statusnya diturunkan menjadi krama gumi pulangan jika yang diajak melangsungkan perkawinan mempunyai kasta atau warga pasek. Jika selain daripada itu akan dibuang atau ditempatkan di Banjar Pande di sebelah Timur Desa Tenganan. Apabila pria mempunyai istri lebih dari satu orang istri, maka tidak lagi menjadi krama desa, tetapi menjadi krama gumi pulangan. Berbeda halnya jika perempuan dari Desa Tenganan yang melangsungkan perkawinan keluar dari Desa Adat Tenganan Pegringsingan, sanksi yang akan dikenakan berupa denda sebesar Rp. 75.000 yang diserahkan kepada desa. Hal ini dapat dilihat dalam awig-awig (aturan) Desa Adat Tenganan Pegringsingan pada angka 6 yang menentukan: 6. Mwah tingkah I wong desa ika sinalih tunggal ngasampingangpiyanak nyane, wiyadin nyama luh, mwah nyolongang kacolongan, pada tan kawasa, ika wnang kadanda olih desa, gung arta Rp. 75.000, mantuk ka desa saunggal Terjemahan, perihal barang siapa membiarkan kawin keluar desa anaknya maupun saudara wanitanya atau ikut memberi kesempatan sama sekali dilarang serta didenda oleh desa sebesar Rp. 75.000, diserahkan kepada desa semuanya.

Apabila pihak perempuan yang diajak untuk melangsungkan perkawinan tidak memiliki kasta dan bukan warga pasek maka, laki-laki dari Desa Adat Tenganan Pegringsingan dan istri perempuannya akan dikenakan sanksi berupa seperti ditempatkan di Banjar Pande sebelah timur Desa Adat Tenganan Pegringsingan. Perempuan dari orang Desa Adat Tenganan Pegringsingan yang kawin keluar selain dikenakan sanksi denda juga yaitu apabila suatu saat bercerai dengan suaminya tidak dapat lagi kembali ke Desa Tenganan Pegringsingan dan menjadi krama desa Tenganan Pegringsingan. Orang tua dari si perempuan juga akan dikenakan sank i denda berupa uang kepeng sebesar 2.000 (wawancara dengan I Wayan Rustana tanggal 1 Desember 2020).

Salah satu responden bernama I Made Sudiarsana yang sudah menikah hampir 8 tahun, merupakan asli warga Desa Adat Tenganan dan istrinya berasal dari Bangli, Kintamani. Menurut responden sanksi tidak ada diberikan kepadanya hanya tidak ikut sebagai krama desa saja dan pada saat ngayah juga sudah beda, ada bagian-bagian khusus yang sudah terbagi untuk setiap krama. Kalau pihak laki-laki dari Desa Adat Tenganan Pegringsingan kawin dengan perempuan diluar Desa Adat Tenganan yang tidak menak (berkasta) dan bukan warga pasek ditempatkan di Banjar Pande, sanksinya hanya dipindahkan ke Banjar Pande saja karena orang Banjar Pande tidak ikut upacara di Tenganan Pegringsingan. Jika pihak perempuan dari Desa Adat Tenganan yang kawin keluar maka akan dikenakan sanksi 2.000 uang kepeng seumur hidup sampai orang tuanya tiada dikenakan setiap sasih. kedasa (setiap tahun). 


\section{SIMPULANDAN SARAN}

\section{Simpulan}

Dari hasil analisis data, dapat disimpulkan bahwa hasil penelitian ini menunjukkan status krama lakiIaki di Desa Tenganan Pegringsingan yang melangsungkan perkawinan dengan perempuan dari luar Desa Adat Tenganan Pegringsingan dan bukan berasal dari warga pasek, mereka akan diturunkan statusnya dari krama desa menjadi krama gumi pulangan dan ditempatkan di Banjar Pande yang berada di sebelah Timur Desa Tenganan, sehingga mereka akan kehilangan hak dan kewajibannya di Desa Adat Tenganan Pegringsingan. Pihak perempuan yang dari keluarga warga pasek dikecualikan karena zaman dahulu yang dianggap kasta itu adalah dari warga pasek, selanjutnya sanksi bagi lakilaki dari Desa Adat Tenganan Pegringsingan yang mengambil seorang istri dari luar Desa Adat Tenganan Pegringsingan kecuali warga pasek, maka orang yang demikian tidak diakui lagi sebagai warga Desa Adat Tenganan Pegringsingan atau tidak diperkenankan sebagai krama desa dan tidak lagi berada di wilayah desa tersebut tetapi ditempatkan di Banjar Pande yang berada di sebelah timur dari Desa Tenganan Pegringsingan serta diasingkan dari Desa Adat Tenganan Pegringsingan. Tanpa menjadi krama desa mereka tidak boleh duduk di dalam struktur sosial.

\section{Saran}

Dari hasil penelitian di atas, peneliti memberika saran yaitu diharapkan kepada masyarakat Desa Adat Tenganan Pegringsingan agar menikah dengan ketentuan Endogami, agar tidak dibuang dari desa dan diturunkan status kramnya. Diharapkan kepada Kelian desa dan pengurus perangkat desa juga harus memberikan pemahaman dan pengertian tentang perkawinan yang berlaku di desa, sehingga kesadaran untuk warga desa Adat Tenganan Pegringsingan dalam mempertahankan status kramanya menjadi semakin tinggi.

\section{DAFTAR PUSTAKA}

Aristoni, \& Abdullah, J. (2016). 4 Dekade Hukum Perkawinan di Indonesia : Menelisik Problematika Hukum dalam Perkawinan di Era Modernisasi. Yudisia, 7(1), 74-97.

Dornikus, R. (2015). Hukum Perkawinan dan Waris Adat di Indonesia. Sura Baya: Laksbang Presindo.

Fuady, M. (2014). Konsep Hukum Perdata PT Raja Grafindo Persada Jakarta. Jakarta: Raja Grafindo Persada.

Hadikusuma, H. (2007). Hukum Perkawinan Indonesia. Bandung: CY. Mundur Maju.

Ketut, W. (2008). Tradisi Desa Bali Kuna Tenganan Pegringsingan. Yogyakarta: Pertama Ruas Media.

Sudarma, I. P., \& Wisuda, P. P. T. (2018). Sanksi Adat pada Larangan Perkawinan Exogami di Desa Pakraman Tenganan Pegringsingan, Desa Tenganan, Kecamatan Manggis, Kabupaten Karangasem, Provinsi Bali. Jurnal Sanjiwani, 9(1), 14-32.

Sugiyono. (2013). Metode Penelitian Pendidikan Pendekatan Kuantitatif dan Kualitatif. Alfabeta.

Sumunar, D. R. S., Suparmini, \& Setyawati, S. (2017). Masyarakat Desa Adat Tenganan Pegringsingan. Jurnal Penelitian Humaniora, 22(2), 111-124.

Yogantara, I. W. L. (2018). Perkawinan Endogami di Desa Tenganan Pegringsingan Karangasem. In Jayapangus Press Books. Jayapangus Press. 